\title{
Survey: to assess the distribution and impact of potato blackleg and soft rot diseases in Zimbabwe
}

\author{
${ }^{1}$ Elizabeth Ngadze, ${ }^{2}$ David Icishahayo \\ ${ }^{1,2}$ Department of Crop Science, University of Zimbabwe, P.O. Box MP167, Mount Pleasant Harare, Zimbabwe
}

\begin{abstract}
A survey to assess the distribution and impact of the potato blackleg/soft rot disease complex in Zimbabwe was conducted from September 2009 to June 2010. Sixty-four questionnaires were collected from 9 potato growing areas in Zimbabwe. The farmers are aware of the existence of soft rot post-harvest decay, seed piece decay and blackleg disease. The most predominant management method for the (three) 3 diseases was the use of rotation cycles with various crops. Estimates of economic losses caused by the diseases ranged from $<1$ to $65 \%$ with the average being approximately 23\%. The most popular cultivars grown in Zimbabwe are Amethyst and BP1, which were ranked as susceptible by more than 50\% of the growers. The disease symptoms are more prevalent at temperatures between $15-20{ }^{\circ} \mathrm{C}$ with moist or humid conditions.
\end{abstract}

Keywords:blackleg, research needs, solanumtuberosum, soft rot, survey,

\section{Introduction}

Potato is one of the most popular food crops grown in Zimbabwe as a substitute staple, third after maize and rice (ChigumirawaNgwerume, 2002). It is widely grown because of its varied uses which include chips, crisps, vegetable relish/salad, canning and livestock feed (Manzira, 2010). In Zimbabwe potatoes have become a common household food because they do not require processing and they are consumed as relish with sadza (thick porridge prepared from maize meal) in many marginalized homes. In most backyard gardens, potatoes are a common crop because peels are thrown into the gardens where they sprout and grow into plants which can be harvested.

Potato is the fourth largest yielding crop in the world after wheat, rice and maize (FAOSTAT, 2010). Although potatoes have the potential to produce high yields per area, they are prone to a wide range of pathogens that drastically reduce yield and quality. Pathogens of major importance are Pectobacterium and Dickeya species, which cause the soft rot/blackleg disease complex. Soft rot bacteria produce large quantities of pectolytic enzymes such as pectinases, pectatelyases, cellulases and proteases which cause tissue maceration (Collmer and Keen, 1986;Pèrombelon, 2002). In Zimbabwe potato growers face the challenge of significant post-harvest losses of tubers ranging from 20 to $80 \%$ (ChigumirawaNgwerume, 2002; Manzira, 2010; Ngadzeet al., 2010) leading to significant financial losses.

In the past, the soft rot/blackleg disease complex was vastly underestimated in Zimbabwe. A severe outbreak of potato soft rot disease occurred in some of the potato growing regions of Zimbabwe in the 2008/9 season. The disease caused severe economic losses in the commercial potato production fields, necessitating research on its epidemiology. A survey was thus carried out in the 2009/10 growing season in order to determine the prevalence and impact of the disease complex in Zimbabwe.

Blackleg and soft rot symptoms are not species specific but are dependent on climatic conditions (Hèlias et al., 2000; De Haan et al., 2008). The diseases are caused by soft rot bacteria formerly known as Erwinia species. Subsequent revisions have led to the taxonomic reclassification of pectolyticErwinia into several genera. Strains formally described as Erwiniacarotovorahave been incorporated into the genus Pectobacterium, and strains classified as Erwiniachrysanthemi are now assigned to the genus Dickeya (Haubenet al., 1998; Gardanet al., 2003; Samson et al., 2005). The bacteria are Gram-negative, non-spore forming, facultative anaerobes, characterized by the production of large quantities of cell wall degrading enzymes which cause disease (Collmer and Keen, 1986).

Pathogenesis of soft rot pathogens is temperature dependent. Pectobacteriumatrosepticum tends to cause blackleg at temperatures $<25^{\circ} \mathrm{C}$ and Dickeya spp. at higher temperatures (Pèrombelon, 2002). Some cold tolerant strains have been found which can cause blackleg symptoms in cool, temperate climates. Pectobacteriumatrosepticum tends to cause blackleg at temperatures $<25^{\circ} \mathrm{C}$ and Dickeya spp. at higher temperatures (Pèrombelon, 2002). Some cold tolerant strains have been found which can cause blackleg symptoms in cool, temperate climates.

Pectobacteriumcarotovorum subsp. carotovorum $(\mathrm{Pcc})$ and Pectobacteriumatrosepticum $(\mathrm{Pa})$ are the primary causes of soft rot in temperate climates. Pectobacteriumcarotovorumsubsp. carotovorumcauses soft rot disease in many plant species and has been isolated from plants with blackleg and aerial stem rot symptoms (Powelson and Apple, 1984). This may be attributed to its survival in many environments (Avrovaet al., 2002), 
whereas Pectobacteriumatrosepticum is largely restricted to potato, usually associated with the blackleg disease (Pèrombelon, 2002). Another more virulent strain, Pectobacteriumcarotovorumsubspbrasiliensis (Pcb), has been identified as the major cause of blackleg and soft rot diseases in Brazil (Duarte et al., 2004), in South Africa (van der Merweet al., 2010) and in Zimbabwe (Ngadze et al., 2012b).

Erwiniachrysanthemi has been reported to be the causal agent of aerial stem rot and wilt disease on potatoes. Taxonomic alteration has separated E. chrysanthemi into six species which all fall in the genus Dickeya. The strains which infect potato have been classified into several of these six species (Samson et al., 2005). These include Dickeyadadantii, Dickeyazeae, Dickeyaparadisiaca, Dickeyachrysanthemi, Dickeyadianthicola and Dickeyadiffienbachiae.

Latent infection of potato tubers by the soft rot pathogens is widespread and disease tends to develop when host resistance is impaired (Pèrombelon and Kelman, 1980) or when environmental conditions are favourable (Pèrombelon, 2002). Bacterial cells remain dormant but numbers can fluctuate depending on tuber storage conditions, increasing under moist and decreasing under dry conditions (Pèrombelon, 2002). The bacteria can survive for several months in the soil, long enough to bridge the gap between cropping seasons (Pèrombelon, 2002). The main environmental factor for a shift from latency to disease development is the presence of water on tubers, which triggers disease development. The film of water on the tubers leads to anaerobiosis and tissue maceration.

In Zimbabwe Pectobacteriumatrosepticum and Pectobacteriumcarotovorum subspecies carotovorumhave been listed as the major pathogens causing blackleg and tuber soft rot diseases respectively (Masukaet al., 1998) and recently P. carotovorum subspecies brasiliensies and D. dadantii have been isolated from potato tubers with typical soft rot symptoms (Ngadzeet al., 2010; Ngadze et al., 2012b). AlthoughPectobacteriumwasabiae, Dickeyazeae, Dickeyachrysanthemi and Dickeyadianthicola have not been identified in Zimbabwe as causal agents of the blackleg/soft rot complex, their existence in the country should not be ignored.

Zimbabwe is divided into five natural regions or agro-ecological zones with rainfall as the main criterion of division. Agricultural production potential of any area in Zimbabwe is dependent on its agroecological classification (Table 1, Fig. 1). Potato seed is mostly produced in Nyanga (Region I) and Harare (Region II) whereas table potato is grown throughout the country as long as there is adequate water for supplementary irrigation. The objective of the study wasinvestigate the farmer's knowledge of soft rot and blackleg diseases, the importance of research to effectively control the disease complex and the perceptions and comments of potato growers regarding the disease in Zimbabwe.

\section{Materials And Methods}

A survey was conducted from September 2009 to June 2010 in three of the five Natural Regions (NR) of Zimbabwe. The survey was carried out in nine potato growing areas, namely, Chinhoyi, Darewndale, Gweru, Harare, Marondera, Mazowe, Nyanga, Shamva and Shurugwi. These areas are representative of the 3 Natural regions selected for the survey. A questionnaire was distributed to seed and table potato growers. Table potato farmers were comprised of large scale and small scale resettled farmers. A random sample of growers in each region completed the questionnaire and thenumber of participants from each region ranged from 15 to 30 based on the number of growers in each region. The questionnaire was divided into four main sections drawn up to determine (i) environmental conditions (average daily maximum temperatures in summer and winter and rainfall) in each region (ii) crop production practices (irrigation, type of seed and cultivars planted) (iii) crop protection including control method; application method for the different fungicides usedto control various diseases; impact of blackleg and soft rot on yield of potato; pre- and post-harvest yield losses and (iv) general crop production practices. Farmers were asked to rank potato cultivars for blackleg, pre- and post-harvest soft rot susceptibility on a scale of 1 to 3 with 3 being susceptible, 2 moderately susceptible and 1 resistant. Farmers were also requested to make suggestions about research priorities and general comments about their perceptions of the disease.

Responses were summarized in a table format for statistical analysis and frequencies for the various parameters were calculated using the SPSS statistical package (SPSS statistics 17.0). The frequencies of answers pertaining to irrigation, chemical control and preference of cultivarswere tested using the analysis of proportions.

\section{Results}

Sixty-four questionnaires were collected from three Natural Regions surveyed. The number of completed questionnaires from each region were as follows Natural Region I (20), Natural Region II (26) and Natural Region III (18)(Table 2). 
Crop production.Sixty-eight percent of the respondents irrigate their potato crop; of these $53.1 \%$ irrigate once a week, $15.6 \%$ twice a week and the remaining $31.3 \%$ follow other irrigation. . The other irrigation schedules mentioned were 2-3 times per week, only in the early part of the season and when necessary. The proportions of growers who followed the different irrigation schedules were significantly different. The comparison of growers who irrigatedweekly versus those who irrigated twice differed significantly $(Z=4.75 ; P=0.000)$. The proportion of farmers who irrigated weekly significantly differed from that of growers who followed other irrigation schedules $(\mathrm{Z}=2.51 ; \mathrm{P}=0.012)$. The proportion of growers who irrigated twice significantly differed from that of farmers who followed other irrigation schedule $(Z=-2.10 ; P=0.036)$ (Table 3). Ninety-two percent of the respondents use certified seed while the remainder retained their own seed.

Control practices. The predominant method for controlling blackleg and soft rot diseases was a 1-2 or 4-5 year crop rotation cycle with Katambora Rhodes grass, maize, beans, onion, ryegrass or left fallow. With regard to chemical control, the growers were aware that chemical control is not effective in controlling blackleg and soft rot diseases, but they used fungicides to control other diseases in the field and in storage. The second widely used method was fungicide application, which was used by $45.3 \%$ of the respondents for the control of various diseases in the field and in storage. Twenty-five percent of the farmers dust the tubers in storage, $5.4 \%$ dip the tubers in fungicide solution prior to planting and $14.9 \%$ spray the plants in the field in order to reduce incidences of fungal diseases. The proportion of respondents who used dust formulations differed significantly from those who dipped tubers prior to planting $(\mathrm{Z}=3.02 ; \mathrm{P}=0.002)$. There was no significant difference in the proportion of respondents who used dust versus spray and dip versus spray (Table 4).

Major potato cultivars grown in Zimbabwe.The majority of the growers $(81 \%)$ planted Amethyst with more than $75 \%$ of these respondents planting in excess of 10 ha to Amethyst. BP1 and Montclare were also popular, planted by $58 \%$ and $32 \%$ of the respondents, respectively. A small proportion of the farmers, $6 \%$ and $2 \%$ grow Pimpernel and Garnet respectively. The proportion of respondents who planted Amethyst, BP1 and Montclare were significantly different. The proportion of respondents who planted Amethystversus BP1 differed significantly $(\mathrm{Z}=2.98 ; \mathrm{P}=0.003)$. The proportion of respondents who planted Amethyst versus those who planted Montclare differed significantly $(Z=6.35 ; \mathrm{P}=0.000)$. The proportion of respondents who planted BP1 significantly differed from that of those who planted Montclare $(Z=2.93 ; P=0.003)$. The other cultivars Mondial, Hertha, KY20 and Mnandi were grown by between 1\% and 3\% of the farmers.

Estimated economic losses.Economic losses due to blackleg, soft rot and seed piece decay ranged from $<1 \%$ to $65 \%$, with the average being $23 \%$ (Table 3 ). Only $56 \%$ of the respondents answered this question.

Ranked susceptibility of cultivars.BP1, the second most popular cultivar, was rated as the most susceptible variety. Eighty-one percent of the respondents answered this question; 70\% ranked BP1 as the most susceptible, $33.8 \%$ as moderately susceptible and only $6.2 \%$ as resistant. Amethyst, the most popular variety, was ranked as susceptible by $60.5 \%$, moderately susceptible by $24.8 \%$ while $4.7 \%$ ranked it as resistant. Montclare, which is grown by $15 \%$ of the respondents, was ranked as resistant by $6.2 \%$ while the remaining $9.4 \%$ ranked it as moderately susceptible. Pimpernel and Garnet were ranked as resistant by all the respondents and they are grown on contract for the company which produces potato crisps.

Areas of research requested by farmers.The section was completed by $85 \%$ of the respondents and $75 \%$ of them highlighted that there was a need for research on the disease in Zimbabwe. Some of the respondents cited more than one research area. The areas of research requested by growers were summarized as follows (numbers of respondents citing area of research is shown in parenthesis):

- Effective control methods (45)

- Evaluation/selection of resistant cultivars (20)

- Breeding for resistance (15)

- Survival period of the causal pathogens in soil and alternate hosts (30)

General comments of respondents. Comments were summarized as follows:

- Soft rot and blackleg disease prevalence increasing especially during wet periods followed by warm to dry temperatures.

- Soft rot incidence higher in potatoes harvested from wet soil.

- Enclosed storerooms result in higher soft rot incidence than open sheds

- Few tubers rot in storage but after emergence plants show symptoms of wilting

- A high proportion of tubers rot during transportation especially when covered 


\section{Discussion}

Although the majority of growers plant certified seed, this is not likely to affect the disease situation in the country asthe potato seed certification scheme relies solely on visual inspection of the crop in the field and the tubers after harvesting. Many commercial seed grade stocks are contaminated (or latently infected) with bacteria found mainly in the lenticels and suberized wounds on tubers (Pérombelon and Kelman, 1980). Tuber contamination can occur before, during or after harvest and several sources of contamination have been identified which include tubers, irrigation water, machinery and insects. Detection and identification of soft rot pathogens in all potato growing regions is hampered by lack of reliable and sensitive diagnostic tools to detect the latent infections in seed (Czajwoskiet al., 2009). The yield losses caused by blackleg and soft rot will not be reduced until the latent infections can be detected in seed lots.

It was interesting to note that both cultivars Amethyst and BP1, ranked by the majority of farmers and by Ngadze et al. (2012a) as susceptible are still widely grown. The choice of these two cultivars might be attributed to physiological characteristics and yield. The yield for these cultivars has been reported to be in excess of 30 tonnes ha ${ }^{-1}$ under good management practices (Manzira, 2010). Pimpernel and Garnet which were ranked as resistant cultivars are grown by a few farmers who are contracted by the companies which use them for making crisps. These two cultivars are not preferred by consumers because of their poor culinary properties. They are not as high yielding as Amethyst and BP1 (Manzira, 2010).

From the responses, it was evident that the growers were aware of blackleg and soft rot diseases and this survey has confirmed reports of yield losses as high as $90 \%$ if tubers are not handled properly (ChigumirawaNgwerume, 2002, Manzira, 2010). The differences in estimated yield losses between natural regions could be attributed to a number of factors such control practices, cultivars grown, different perceptions about the disease and different climatic conditions. According to the results obtained in this study, the highest yield losses due to the soft rot/blackleg complex were recorded in Darwendale followed by Mazowe and Harare. All these areas fall in Natural Region II, characterised by average maximum summer temperatures of $21-25^{\circ} \mathrm{C}$ and average maximum winter temperatures of $10-15^{\circ} \mathrm{C}$.Pectobacteriumcarotovorum subspecies carotovorum, P. carotovorum subspecies brasiliensis and Dickeyadadantii were identified as the causal agents of the blackleg/soft rot disease complex (Ngadze et al., 2012b). The region receives an average annual rainfall of 750 - $1000 \mathrm{~mm}$ and $70 \%$ of the farmers irrigate their crop. Marondera, an area found in the same natural region, recorded lower disease incidences because it is much colder than the other areas in the same region. The average yield losses in Natural Region II ranged from 9 to $40 \%$ and countrywide the average yield losses are around 23\%. Yield losses were also reported to be high in Chinhoyi and Shamva (Natural Region III). The rainfall received in this region is not adequate for potato production and all the farmers irrigate their crop. Most of the respondents in this region irrigated their crop more frequently than respondents from the other regions. Nyanga, found in Natural Region I has the lowest disease incidence. Disease incidence and severity of blackleg and soft rot diseases depend on temperature and free water (Pérombelon, 2002; Toth et al., 2003). Conditions optimal for blackleg and soft rot development are between 15 and $25^{\circ} \mathrm{C}$ with prevailing wet conditions.

Some of the research areas requested by farmers covered information already known by scientists, for example, the issue pertaining to survival of the pathogen in the soil and alternate hosts. This shows that there is a knowledge gap that can be bridged by scientists networking and collaborating with the farmers. Farmers should participate in some of the trials dealing with evaluation of cultivars for resistance to the pathogens and selection of effective control strategies. This exercise is important since chemical control is not effective in controlling soft rot pathogens, control strategies rely on cultural practices and Integrated Pest Management (IPM) strategies. Good disease management practices are based on farmers' level of knowledge and ability to make control decisions effectively in implementing IPM strategies (McRoberts et al., 2003). The success of IPM system depends on regular transfer of knowledge between scientists, agronomists and growers to ensure early disease prediction, effective implementation of sustainable practice and continual improvement ofmanagement practices (Ingram, 2008).

Research in Zimbabwe should focus on identification of effective control strategies and epidemiological studies in order to understand the disease development process in the country. Since blackleg and soft rot diseases originate from infected seed tubers, research should focus on the development of reliable and sensitive pathogen detection techniques which can be used in the screening of seed tubers. The research should also focus on the development and screening of resistant cultivars.

\section{Acknowledgements}

The authors would like to thank the extension officers and industry representatives who helped in the distribution and collection of questionnaires, as well as the growers who completed questionnaires. 


\section{References}

[1] Avrova, A.O., Hyman, L.J., Toth, R.L., Toth, I.K., 2002. Application of amplified fragment length polymorphism fingerprinting for taxonomy and identification of the soft rot bacteria Erwinia carotovora and Erwinia chrysanthemi. Applied Environmental Microbiology68:1499-1508.

[2] Chigumira waNgwerume, F., 2002. Growing Potatoes. National Farmer's Training Board (NFTB). Marondera, Zimbabwe.

[3] Collmer, A., Keen, N.T., 1986. The role of pectic enzymes in plant pathogenesis. Annual Review Phytopathology24:383-409.

[4] Czajkowski, R., Grabe, G.J., van der Wolf, J.M., 2009. Distribution of Dickeya spp. and Pectobacterium carotovorum subsp. carotovorumin naturally infected seed potatoes. European Journal Plant Pathology125:263-275.

[5] De Haan, E.G., Dekker-Nooren, T.C.E.M., Van den Bovenkamp, G.W., Speksnijder, A.G.C.L., van der Zouwen, P.S. and Van der Wolf, J.M., 2008. Pectobacterium carotovorum subsp. carotovorum can cause potato blackleg in temperate climates. European Journal Plant Pathology 122:561-568.

[6] Duarte, V., De Boer, S.H., Ward, L.J., De Oliveira, A.M.R.,2004. Characterization of atypical Erwinia carotovora strains causing blackleg of potato in Brazilian Journal Applied Microbiology96:535-545.

[7] FAOSTAT, 2010. FAOSTAT. Available at http://faostat.fao.org/site/339/default.aspx [Accessed May 25 2011]

[8] Gardan, L., Gouy, C., Christen, R., Samson R.,2003. Elevation of three subspecies of Pectobacterium carotovora to species level: Pectobacterium atrosepticum sp. nov., Pectobacterium betavasculorum sp. nov.and Pectobacterium wasabiae sp. nov.International Journal Systematic Evolutionary Microbiology53:381-391.

[9] Hauben, L., Moore, E.R., Vauterin, L., Steenackers, M., Mergaert, J., Verdonck, L., Swings, J., 1998. Phylogenetic position phytopathogens within Enterobacteriaceae. Systematic Applied Microbiology21:384-397.

[10] Hèlias, V., Andrivon, D., Jouan, B., 2000. Developments of symptoms caused by Erwinia carotovora ssp. atroseptica under field condition and their effect on the yield of individual potato plants. Plant Pathology 49:23-32.

[11] Ingram, J., 2008. Agronomist-Farmer knowledge encounters. An analysis of knowledge in the context of best management practices in England. Agri. Hum. Val. 25:405-418.

[12] Manzira, C., 2010. Potato production handbook. Potato Seed Association Zimbabwe.

[13] Masuka, A.J., Cole D.L., Mguni, C., 1998. List of plant diseases in Zimbabwe. Plant Protection Research Institute, Zimbabwe pp 122 and 86.

[14] McRoberts, N., Hughes, G., Savary, S., 2003. Integrated approaches to understanding and control of diseases and pests in field crops. Australian Plant Pathology 32:167-180.

[15] Ngadze, E., Coutinho, T.A., Icishahayo, D., van der Waals, J.E., 2012a. Role of polyphenol oxidase peroxidise, phenylalanine ammonia lyase, chlorogenic acid and total soluble phenols in resistance of potatoes to soft rot. Plant Disease 96:186-192.

[16] Ngadze, E., Coutinho, T.A., van der Waals, J.E., 2010. First report of soft rot of potatoes $\quad$ caused by Dickeya dadantii in Zimbabwe. Plant Disease94:1263.

[17] Ngadze, E., Coutinho, T.A., van der Waals, J.E., 2012b. Pectinolytic bacteria associated with potato soft rot and blackleg in South Africa and Zimbabwe. European Journal Plant Pathology 134:533-549.

[18] Pérombelon, M.C.M., 2002. Potato diseases caused by soft rot erwinias: an overview of pathogenesis. Plant Pathology51:1-12.

[19] Pérombelon, M.C.M., Kelman, A., 1980. Ecology of soft rot Erwinias. Annual Review Phytopathology18:361-67.

[20] Powelson, M.L., Apple, J.D., 1984. Soil and seed tubers as sources of inoculums of Erwinia carotovora subsp carotovora for stem soft rot of potatoes. Phytopathology 74:429 - 432 .

[21] Samson, R., Legendre, J.B., Christen, R., Fischer-Le Saux, M., Achouak, W., Gardan, L., 2005. Transfer of Pectobacteriumchrysanthemi (Burkholderet al., 1953) Brenner et al., 1973 and Brenneria paradisiaca to the genus Dickeya gen. nov. known as Dickeya chrysanthemi comb. nov andDickeyaparadisiaca combi. nov. and delineation of four novel species, Dickeya dadantii sp nov.,Dickeya dianthicola sp. nov.,Dickeya diefferenbachiae sp. nov. and Dickeya zeae sp. nov. International Journal Systematic Evolutionary Microbiology55:1415-1427.

[22] Toth, I.K., Bell, K.S., Holeva, M.C., Birch, P.R.J., 2003. Soft rot erwinia: from genes to genomes. Molecular Plant Pathology 4:1730.

[23] Van der Merwe, J.J., Coutinho, T.A., Korsten, L., van der Waals, J.E., 2010. Pectobacterium carotovorum subsp. brasiliensis causing blackleg on potatoes in South Africa. European Journal Plant Pathology 126:175-185.

TABLE 1 Rainfall characteristics of the five agro-ecological zones of Zimbabwe and suitable agricultural activities (adapted from FAO

\begin{tabular}{|c|c|c|c|c|}
\hline $\begin{array}{l}\text { Agro- } \\
\text { ecological } \\
\text { zone } \\
\end{array}$ & $\begin{array}{l}\text { Area } \\
\left(\mathrm{km}^{2}\right)\end{array}$ & $\begin{array}{l}\% \text { of } \\
\text { total }\end{array}$ & $\begin{array}{l}\text { Rainfall } \\
\text { Characteristics }\end{array}$ & Agricultural activities \\
\hline $\mathrm{I}$ & 7,000 & 2 & $\begin{array}{l}\text { More than } 1050 \mathrm{~mm} \text { per } \\
\text { annum with some rain in all } \\
\text { months }\end{array}$ & $\begin{array}{l}\text { Specialized and diversified farming region. Suitable for forestry, } \\
\text { temperate fruit and intensive livestock production }\end{array}$ \\
\hline II & 58,600 & 15 & $\begin{array}{l}700-1050 \mathrm{~mm} \text { confined to } \\
\text { summer. Infrequent heavy } \\
\text { rainfall. Subject to seasonal } \\
\text { droughts }\end{array}$ & $\begin{array}{l}\text { Flue-cured tobacco, maize, soybean, cotton, sugar beans and coffee } \\
\text { can be grown. Sorghum, groundnuts, seed maize, wheat and barley } \\
\text { are also grown. Wheat and barley grown in winter under irrigation. } \\
\text { Mixed cropping with poultry, beef and dairy production common. }\end{array}$ \\
\hline III & 72,900 & 18 & $\begin{array}{l}500-700 \mathrm{~mm} \text { per annum. } \\
\text { Infrequent heavy rainfall. Subject } \\
\text { to periodic seasonal droughts, } \\
\text { prolonged mid season dry spells } \\
\text { and unreliable starts of the season. }\end{array}$ & $\begin{array}{l}\text { A semi intensive farming area. Smallholder farmers occupied } 39 \% \text { of this } \\
\text { area and most of the land was used for extensive ranching before resettlement } \\
\text { in } 2000 \text {. Maize production dominated commercial production. Irrigation } \\
\text { played an important role in sustaining crop production in commercial farming } \\
\text { areas. }\end{array}$ \\
\hline IV & 147,800 & 38 & $450-600 \mathrm{~mm}$ per annum & $\begin{array}{l}\text { Suitable for extensive ranching and wildlife management. Too dry } \\
\text { for successful crop production of most crops suitable for sorghum } \\
\text { and millets and other drought tolerant crops. Maize is commonly } \\
\text { grown by smallholder farmers. Sugar cane and cotton are produced } \\
\text { under irrigation in large estates. }\end{array}$ \\
\hline
\end{tabular}


Survey: to assess the distribution and impact of potato blackleg and soft rot diseases in Zimbabwe

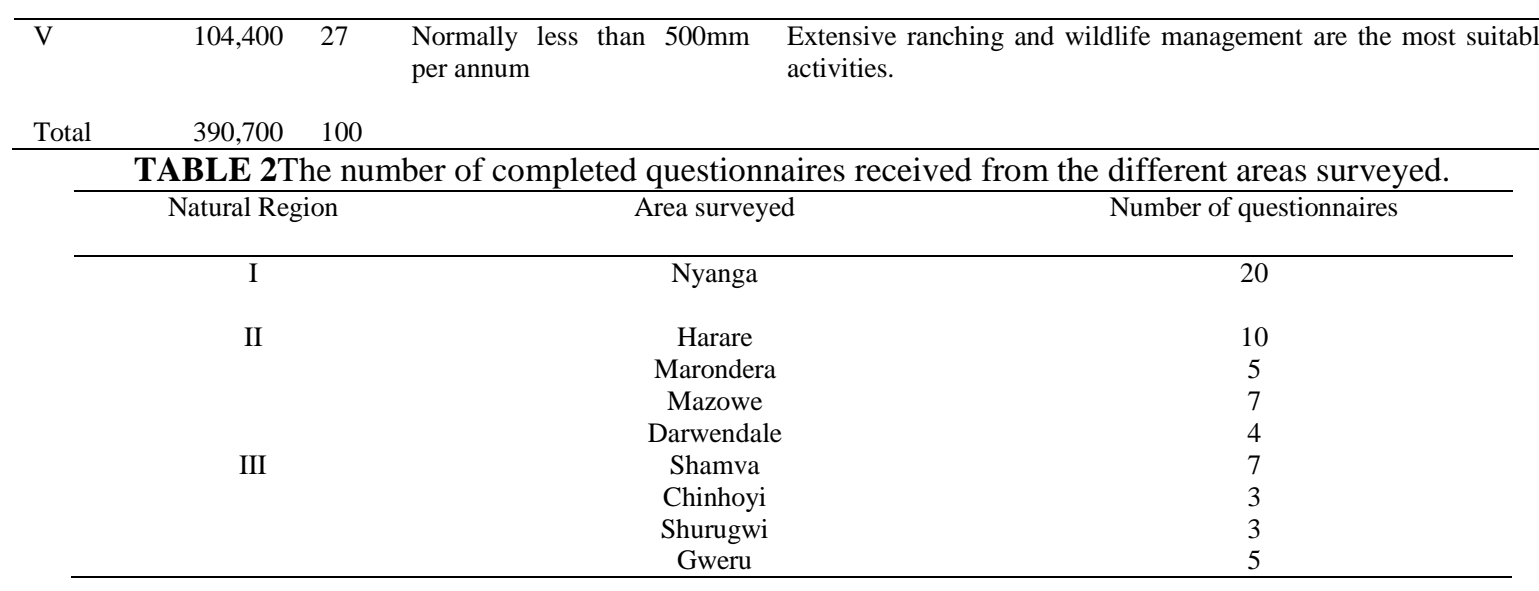

TABLE 3Comparison of proportions of respondents who used the different irrigation schedules

\begin{tabular}{lcc}
\hline Comparison & $\mathrm{z}$ & $\mathrm{P}$ \\
\hline Weekly (34) vs twice (10) & 4.75 & 0.000 \\
Weekly (34) vs others (20) & 2.51 & 0.012 \\
Twice (10) vs others (20) & -2.10 & 0.036 \\
\hline
\end{tabular}

TABLE 4Comparison of proportions of respondents who used the different chemical control methods

\begin{tabular}{lll}
\hline Comparison & $\mathrm{z}$ & $\mathrm{P}$ \\
\hline Dust (16) vs dip (4) & 3.02 & 0.002 \\
Dust (16) vs spray (10) & 1.33 & 0.184 \\
Dip (4) vs spray (10) & 1.72 & 0.086 \\
\hline
\end{tabular}

TABLE 5Comparison of proportions of respondents who planted different cultivars

\begin{tabular}{lll}
\hline Comparison & $\mathrm{z}$ & $\mathrm{P}$ \\
\hline Amethyst (52) vs B P1 (37) & 2.98 & 0.003 \\
Amethyst (52) vs Montclare (21) & 6.35 & 0.000 \\
BP1 (37) vs Montclare (21) & 2.93 & 0.003 \\
\hline
\end{tabular}

TABLE 6Mean estimated yield losses due to pre- and post-harvest soft rot and blackleg losses in potato growing regions of Zimbabwe.

\begin{tabular}{lccc}
\hline \multicolumn{1}{c}{ Potato growing Region } & $\begin{array}{c}\text { Soft rot seed piece decay post } \\
\text { planting }(\%)\end{array}$ & $\begin{array}{c}\text { Blackleg (Pectobacterium } \\
\text { wilting) }(\%)\end{array}$ & $\begin{array}{c}\text { Soft rot postharvest } \\
(\%)\end{array}$ \\
\hline Nyanga & 2 & 5 & 10 \\
Harare & 21 & 10 & 20 \\
Marondera & 8 & 3 & 5 \\
Mazowe & 20 & 8 & 35 \\
Darwendale & 40 & 10 & 65 \\
Shamva & 8 & 15 & 20 \\
Chinhoyi & 10 & $<1$ & 20 \\
Gweru & $<1$ & 2 & 10 \\
Shurugwi & 0 & 1 & 5 \\
\hline
\end{tabular}




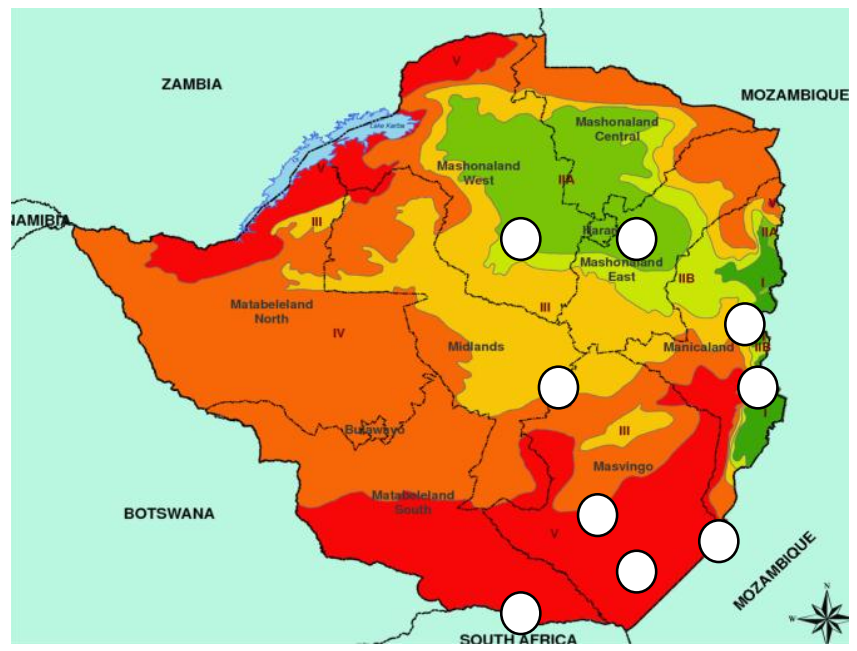

Figure 1 Map showing the natural regions of Zimbabwe. Areas surveyed are shown by white circles. (Adapted from http://relifweb.int/sites) 